\title{
Apprentice Watch: Learning Through Reality TV
}

\author{
Susan P. Eisner, (E-mail: seisner@ramapo.edu), Ramapo College of New Jersey
}

\begin{abstract}
The Apprentice attracts younger viewers in record number. Most of today's college students fall within that range. This paper presents pedagogy created to use The Apprentice in business school teaching.
\end{abstract}

\section{INTRODUCTION}

6.7 n December 15, 2005, 27.6 million people watched Donald Trump hire Randall Pickett in the series finale of season four of the NBC reality television series, The Apprentice. It was not because Mr. Pickett is the founder of a consulting firm in the state of New Jersey (Apprentice Finale Boosts NBC, 2005) where Ramapo College is located that many of its students watched as Donald Trump said, "You're Hired." Like the three apprentices selected by Mr. Trump at the end of prior seasons, 34-year old Mr. Pickett is a cohort of an audience segment the series targets and regularly attracts: younger viewers, aged 18-49 - the viewers most valued by advertisers (Muscato, 2004), and the age group of most college students. So many young viewers watched The Apprentice finale that NBC beat out competing stations that night in the key 18-49 demographic (Apprentice Finale Boosts NBC, 2005). In doing so, it continued the trend established in its first season when The Apprentice ranked overall second only to American Idol in young adult viewing (Levin, 2004), and in its second season when it again finished strong among young adult viewers (Apprentice Heading to Broadway, 2005).

What are young viewers seeing when they watch The Apprentice? Business School Dean Denis Fred Simon describes this hit series as spotlighting men and women working in teams "to tackle on-the-spot business challenges requiring considerable personal talent, nerve, and commitment to radical innovation ... Donald Trump establishes a 'trial-by-fire' atmosphere in which each participant sees immediately the cause-and-effect consequences of any business action" (Simon, 2004). Series creator and co-executive producer Mark Burnett explains the dynamics of The Apprentice this way, "(It has) a bunch of really smart people, who all want to be top dog, and they can't all be it ... It's fascinating to watch them melt down each week ... I can't believe people this smart make the mistakes they make, and Donald (Trump) doesn't miss anything" (Levin, 2004). This would seem to be a reality that college students would relate to, and want to understand.

Before becoming a college professor teaching business management courses, many years were spent working in television programming and related communication functions. As a result, by experience ${ }^{1}$ and prior training, ${ }^{2}$ knowing one's audience and creating messages and formats that will attract and retain their interest and attention is a natural starting place when seeking to engage students. With that frame of reference, The Apprentice was an interesting pedagogical tool to contemplate. Its focus on the hiring process parallels a key interest of most college students, its competitions utilize and assess core competencies taught in classes they take, and its twin emphases on teamwork and leadership mirror essential skill sets of contemporary business education.

A review of the literature reveals that others found The Apprentice an interesting pedagogical tool, too. The University of Washington at Seattle (Deggans, 2004), Northern Illinois University (Apprentice NIU Style, 2004), University of San Francisco (Lee, 2004), University of Pittsburgh (Johnson, 2004), Brandeis University, and Ohio State University (Talcott, 2004) are among those who have reported the use of The Apprentice as a college teaching tool. Donald Trump reports mandatory viewing at Harvard and Wharton Business Schools (Naughton, 2004). This paper presents original pedagogy created to enhance the learning value of The Apprentice for undergraduate students 
at the School of Business at Ramapo College of New Jersey. Foundations, assignments, and assessment methods are described, for those who may be contemplating similar usage in their own classes.

\section{FOUNDATIONS}

In reviewing the existing literature, more than 100 articles were located online through academic databases including ProQuest, Academic Search Premiere, and LexisNexis. TV programs - The Apprentice, lessons learned from The Apprentice, The Apprentice and college, The Apprentice and teaching, and The Apprentice and business were among the search locators. Practitioner websites were also searched using those locators.

A review of the literature reveals the breadth of the impact The Apprentice has made. Lessons learned from this television series have been publicly distributed on websites ranging from the NBC broadcaster (www.nbc.com/nbc), to college career centers (career.berkeley.edu), to online career sites ( $\underline{\mathrm{msn} . c a r e e r b u i l d e r . c o m})$, to online news sites (realitynewsonline.com). The American Management Association website (www.amanet.org) featured a detailed follow up with skill building how to's written by its President and CEO for every episode of seasons two and three of The Apprentice. USA Today has carried a weekly column by a corporate executive and management consultant analyzing individual episodes of The Apprentice (Deggans, 2004), and the general media has been chronicling the perspectives of managers (Purdy, 2004), executive coaches (Moriaraty, 2005), and business school students and faculty (Cadden, 2004; Ho, 2004; Johnson, 2004; Simon, 2004; Talcott, 2004) regarding lessons learned from this TV series.

When response to season one of The Apprentice revealed it to be a phenomenon, Newsweek featured a story entitled "The World According to Trump" (Naughton, 2004). The article identified seven tenets of business success held by Mr. Trump who, as co-executive producer, provides some of the series' vision. Figure 1 provides these foundations.

Figure 1: Donald's 7 rules of success (Naughton, 2004)

1. You have to be born with enough brainpower.

2. Once you have that, you have to love what you're doing. I've never seen anyone succeed who didn't love what they were doing.

3. You cannot stop. If there is a concrete wall in front of you, you have to go through it. You can never, ever give up or even think in terms of giving up.

4. Confidence is a very important thing. But confidence isn't something you just develop by saying "I'm going to do this or that." You really have to believe it.

5. I love pitting people against each other. My whole life is based on that. It brings out the best in people and the worst in people. If the worst comes out, you don't want them working for you.

6. You have to remain cool under fire and let criticism roll off of you. Good leaders handle conflict easily and bad ones are eaten up by it.

7. You must work well with others and be loyal to your team. Disloyalty is the worst of all traits. I seldom use the words "You're fired!" in business, unless somebody is really scum and stole from me.

How do those tenets translate to The Apprentice? Figure 2 contains representative lessons to be learned by watching the series as reported by news and career websites (MSN Careers, 2004; Career Center, 2005; Bloomberg, 2005). 
Figure 2: Lessons learned from The Apprentice according to career and news websites.

\begin{tabular}{|c|c|c|}
\hline$\frac{\text { How To Succeed In Business Msn }}{\text { Careers }}$ & $\frac{\text { How To Interview Well College }}{\text { Career Center }}$ & $\frac{\text { How To Be Hired By Trump Reality }}{\text { (Realitynewsonline.Com) }}$ \\
\hline $\begin{array}{l}\text { 1. Have a strategy } \\
\text { 2. Find out what the boss/client } \\
\text { wants and give it to him/her } \\
\text { 3. Deal with the one in charge } \\
\text { 4. Be positive } \\
\text { 5. Have courage to speak your mind } \\
\text { 6. Stand up for yourself } \\
\text { 7. Be flexible } \\
\text { 8. There's life after being fired }\end{array}$ & $\begin{array}{l}\text { 1. Know your customer/target } \\
\text { 2. Demonstrate your product/ } \\
\text { value whenever you can } \\
\text { 3. Build rapport } \\
\text { 4. Anticipate/address objections } \\
\text { 5. Stay on top of your game } \\
\text { 6. Be succinct }\end{array}$ & $\begin{array}{l}\text { 1. Show leadership } \\
\text { 2. Scheming and plotting don't } \\
\text { work, but don't show your hand } \\
\text { 3. Stay cool under fire } \\
\text { 4. Have a backbone } \\
\text { 5. Play well, but stay professional } \\
\text { 6. Focus on the long-term } \\
\text { 7. Think outside the box, but not too far } \\
\text { 8. You can't be one-dimensional } \\
\text { 9. Use common sense }\end{array}$ \\
\hline
\end{tabular}

In many ways, the American Management Association (AMA) website provided me with the most substantive foundation. The areas it extracted for supplemental skill building following each episode in the second and third seasons of The Apprentice coincided with cognitive and applied objectives in the 300-level Business Communication, Organizational Theory and Behavior, and Principles of Contemporary Arts Management courses ${ }^{3}$ I was teaching. The materials provided on the AMA website had the authenticity of being authored by President and CEO Edward T. Reilly, the relevant practitioner emphasis, and the reinforcement value and depth that written material can provide. Figure 3 shows the lessons to be learned in conjunction with The Apprentice through ancillary materials presented on the AMA website (http://www.amanet.org/events/apprentice/lessons_learned, 2005).

Figure 3: Lessons learned from The Apprentice according to the American Management Association website

\section{SEASON 2 (FALL 2004)}

1. Conducting successful creative brainstorming sessions

2. Making sound business decisions

3. Managing a budget

4. Earning respect as a leader

5. Selling persuasively

6. Developing a winning competitive strategy

7. Building a cohesive team

8. Leading with passion

9. Resolving conflicts

10. Managing projects effectively

11. Delegating successfully

12. Communicating with your boss

13. Marketing a new product

14. Interviewing for the job you want

15. Being a top-notch leader

\section{SEASON 3 (SPRING 2005)}

1. Training is key: be broad-based and job-specific

2. Communicating in stressful situations

3. Dealing with negative team members

4. Leveraging attitude: it makes all the difference

5. Listening is an art

6. Marketing creatively: thinking outside of the box

7. Negotiating win-wins

8. Hiring the best

9. Involving customers for sales success

10. Managing emotions in the workplace

11. Making effective presentations

12. Getting buy-in from your team

13. Utilizing focus groups

14. Aligning sales and marketing 


\section{GETTING STARTED}

The foundations were in place. There was relevant learning to be gained from The Apprentice and abundant publicly available material to reference. But where should the pedagogy begin? At Ramapo College, it began simply. Students in various 300-level classes were asked to watch The Apprentice as part of their preparation for class, and to think about what they might apply from each episode that related to the course. Most of the students had already heard about the show and were watching it; those that were hearing about it for the first time said they were interested in watching it. The only constraints were logistics: some expressed concern that The Apprentice aired when they were at work or in another class. Those concerns were allayed as rebroadcast times were given, and students offered to tape episodes.

The anticipated outcome was that students would provide cursory plotline summaries when we next met. Instead, analysis and reflection were such that the allotted discussion time had to be extended to access the learning opportunity that had arisen. Students had not only attended to what they had watched, but had also related to it empathetically. Terms they had been learning seemed to have become situations they could find themselves in. Questions were provocative and instrumental; listening to answers to those questions was rapt.

Where to go from there? An earlier paper describes the "Team Challenge" constructed as one of several learning tools to enhance student engagement through peer-peer learning using team-based competition focused on shared active learning experiences (Click Here for Reality: Enhancing Student Engagement, The College Teaching and Learning Conference Proceedings, 2006). The Team Challenge seemed a natural next step for extending learning from The Apprentice. If individual student learning was so apparent, would the opportunity to debrief about it with peers, present relevant lessons learned as a team, and compete with other teams (for extra credit points) both motivate and extend the learning? That is exactly what The Team Challenge delivered. Through it, the students were in effect competing for success, and experiencing the attendant interpersonal dynamics, like The Apprentice candidates they were following. The classroom was transformed. Students were not only prepared, but they stretched. They edited and presented illustrative video clips. They created and facilitated in-class simulations. They overcame anxiety toward public speaking. They conquered the inevitable challenges of group work. And the Team Challenge vehicle for this assignment delivered an additional benefit: the peer-peer discussions within teams prior to class minimized the amount of in-class time needed for summarization of plotlines. It optimized the use of class time for Apprentice-linked critical thinking, analysis, and application. This was important, as The Apprentice was only one of many pathways to learning being used in the class, and was not to dominate classroom time together. Within this construct, the depth of The Apprentice-based learning as shown in Figure 4 is all the more noteworthy. The following excerpts are from a memo report submitted by a four-person team in an Apprentice-based Team Challenge of a Business Communication class.

Figure 4: Lessons learned from The Apprentice according to an undergraduate student team in a 300-level Business Communication Class (BMGT 307, Ramapo College of New Jersey, March, 2005)

\section{ANALYSIS}

1. A contestant (Michael) was fired for his ineffective communication skills; he didn't know when to speak and how he cuts people off. He lacked the ability to convey himself verbally and nonverbally within the business environment. It is imperative to analyze each situation before you put yourself in the middle of it, and that is exactly what the contestant did not do.

2. Another unsuccessful contestant (Tara) showed strong initiative and creativity, but showed an attitude of a self-oriented role rather than team maintenance or task facilitating role. She was set on her ideas, and was stubborn in accepting ideas or criticism from anyone on her team. She actively chose to inactively listen. In her mind, her ideas would have been wildly successful, but with no back up from her team it was difficult to move forward.

3. John was unable to clearly communicate his idea to his team, especially to the team leader. He had his vision, but was unable to convey it in an effective manner. The others did not understand what he was communicating, and it resulted in a horrible product and total failure. 
4. Alex uses "I" when he talks and does not include his team al the time when he makes decision. He needs to think and plan before he communicates his decisions. If he continues to make decisions without consulting with his group, his group might begin to give bad vibes if his ideas fail. If it is a group decision, regardless if you win or lose no fingers can be pointed. Group cohesiveness is essential in the work world.

5. Stephanie, from start to finish, exemplified ineffective communication that led to her team's demise. Her inability to contribute constructive feedback to decision-making was due to her fear of being fired. She looks at each conflict as a winlose situation in which the outcome always makes one unhappy. The team became stuck in destructive conflict, rather than being able to benefit from creativity and good morale which Stephanie has withheld the group from achieving.

\section{LESSONS LEARNED}

1. Understanding an entire situation whether it is conflict or not is necessary before entering it. If you choose to jump too far ahead you can miss a crucial part of what is going on. Preparedness is a business necessity.

2. Listening is a skill and tasks that can be actively applied across all aspects of communication. Such a fundamental building block of the communicative process is often over looked because people are too busy trying to talk their way through projects and problems that they are not realizing that listening often turns into the fastest way to solve a problem. Whether it is among peers or with a supervisor, listening allows one to learn more about the other person(s) in the conversation as well as giving time to assess the verbal and non-verbal messages that are being sent.

3. A communicator must ensure that his or her message is being sent and delivered the way they intended it to be. Internal and external noise as well as preconceived notions of what should be going on with a project can have an effect on the way a message is received. If the sender of the message takes extra precaution in the manner that they handle their message the outcome of the situation is that much more likely to be positive.

4. It may seem obvious to most, but being part of a team means focusing on the needs and goals of that team. When working in groups it sometimes seems easier to focus on "I" or "my" when discussing the work being done. However, in today's business world more often than not one will find a group or team focused company wants it to be a cohesive group. Although each individual's participation is important and necessary, it is the work as a whole that should be focused on and prioritized.

5. Conflict can also be a double-edged sword in the business world. The way you choose to deal with it can greatly benefit or damage a company. Knowing when destructive and constructive conflict is taking place helps create a better understanding of what is happening in that situation. Constructive criticism can be highly beneficial to a company; it just has to be a choice to not allow destructive criticism to negatively affect a problem.

\section{ASSESSING FURTHER}

In addition to the oral and written evidence illustrated above, concurring anecdotal observations mounted. More students seemed to be enrolling in subsequent courses with this instructor, and asking whether learning from The Apprentice would continue. Several students for whom there were no further courses to take with this instructor asked if they could audit sessions where current episodes of The Apprentice would be learned from. But was the learning transitory? Did the team nature of presenting lessons learned mask individual low performance? Would it translate into traditional academic assessment? With this in mind, an essay question was included in the exams that synthesize course learning at about eight week intervals. Figure 5 contains the essay question that appeared in the Business Communication midterm exam. 
Figure 5: Business Communication midterm exam essay question on lessons learned from The Apprentice

\begin{abstract}
During this semester, the TV series The Apprentice is engaged in a search for the most effective person to fill an executive position in a Trump business. Simultaneously, you are learning about the strategic use of business communication to maximize workplace effectiveness. Applying your learning in this course, assess the communication lessons presented in The Apprentice. Identify and explain $\underline{3}$ terms/concepts from the course relevant to communication scenarios presented in the TV series, and describe $\underline{1}$ specific example of each term/concept from the series. Then, select $\underline{1}$ candidate as the most effective communicator, and 1 candidate as the least effective communicator. Support that decision referring to examples from the course textbook, cases, or videos. Then, describe the $\underline{3}$ most important lessons learned regarding business communication from The Apprentice. Conclude thoughtfully, and raise $\underline{1}$ relevant critical thinking question. Your learning from the course and textbook must be clear.

Use this format:

\section{Introduction}

Analysis

1. Course terms illustrated/explained (1-3)

2. The Apprentice examples of the terms (1-3)

3. The candidates as communicators: strongest/why (support with $\underline{1}$ course material example), and weakest/why (support with 1 course material example)

4. Lessons learned (1-3)
\end{abstract}

Conclusion (include a critical thinking question)

The midterm and final exams are long form tests that include both short answer and essay questions. Each student is expected to take one hour to complete one essay question, and is given several essay questions to select from. Evidencing student engagement with Apprentice-based learning, the majority of students chose to answer essay questions that assess that learning, even though those questions were not the easiest to answer. Essay answers not only showed retained and individual learning, but also reflection enhanced by the assessment process itself. As a result, an essay question targeted to learning objectives in the Organizational Theory and Behavior and Principles of Contemporary Arts Management courses was constructed this semester. Figure 6 contains that essay question.

Figure 6: Organizational Theory and Behavior and Principles of Contemporary Arts Management midterm exam essay questions on lessons learned from The Apprentice

The TV series The Apprentice is engaged in a search for the highest performers to fill executive positions in the Trump organization and Martha Stewart Living Omnimedia. Simultaneously, you have been learning what high performance is and what it depends on. Applying your learning in this course, assess the proscriptions presented in The Apprentice by identifying and explaining $\underline{5}$ terms/concepts from the course relevant to scenarios presented in the current season of The Apprentice: Donald Trump and/or The Apprentice: Martha Stewart TV series, describing 1 specific example of each term/concept for the series, and agreeing or disagreeing with one of the decisions to fire. Support that opinion referring to $\underline{3}$ examples from your textbook, its cases, or current events as proof. Include a thoughtful introduction; conclude providing the most important lesson learned, and 1 relevant critical thinking question. Your learning from this course and its textbook must be clear. Use this format:

\title{
Introduction
}

\section{Analysis}

1. Course terms illustrated (1-5)

2. The Apprentice examples of the terms (1-5)

3. Agree or disagree with Mr. Trump's decision to fire/supported (3 text/case/current event examples)

Conclusion (include most important lesson learned, and a critical thinking question 
What of students whose learning from The Apprentice included prioritizing the importance of developing the interpersonal workplace skills correlated with individual and team high performance? To support and further those objectives, an assignment was prepared that incorporated the materials cited earlier created by The American Management Association to extend Apprentice-based learning. To accommodate diverse student interest in and need for development of these competencies, the assignment was offered two ways. Students could opt to complete it as a graded final project or, less intensively, for optional extra credit. Figure 7 shows the final project option.

Further evidencing the learning value of The Apprentice in business education, the majority of students opted for the AMA-based final project designed to extend competencies in skill-sets illustrated in The Apprentice. Further, performance tended to be higher among those who chose the AMA-based final project option - even though it was more intensive and required more extrapolation than other choices offered to students.

\title{
Figure 7: AMA- based interpersonal skill-building final project option
}

\begin{abstract}
In conjunction with The Apprentice, the American Management Association has prepared materials to help develop the interpersonal and organizational skills relevant to situations presented on the TV series. These materials were made publicly available through the NBC Apprentice website, and at the AMA website (http://www.amanet.org). You need not have watched The Apprentice to learn from or apply these materials. If you choose this option, select the material supplementing any $\underline{10}$ episodes of The Apprentice. For each of the $\underline{10}$ episodes selected, describe the related skill-set, explain key strengths you possess, identify areas to be improved upon, and provide key lessons learned. Include at least 1 example from course material and/or your experience when analyzing each skill. After completing the inventories, identify $\underline{1}$ actual work or school situation that would benefit from your applying at least $\underline{1}$ or the skill-sets, and discuss how you will apply that skill-set to achieve higher performance in that situation. Include a thoughtful introduction, and a reflective conclusion. Be specific, detailed, and thorough. Use this format:
\end{abstract}

\section{Introduction}

\section{Analysis}

1. Skill-set 1: Identify the season and episode number

- Description of the relevant skill-set:

- Strengths:

- Need to improve:

- Lessons Learned:

2. Skill-set 2: (same format as above)

3. Skill-set 3: (same format as above)

4. Skill-set 4: (same format as above)

5. Skill-set 5: (same format as above)

6. Skill-set 6: (same format as above)

7. Skill-set 7: (same format as above)

8. Skill-set 8: (same format as above)

9. Skill-set 9: (same format as above)

10. Skill-set 10: (same format as above)

Application (1 actual situation in which you should apply 1 skill set, why and how)

Conclusion

\section{REALITY CHECK}

As measured through classroom preparation, participation, level of dialog, oral presentation, written reports, and essay questions on exams, using The Apprentice as a teaching tool appeared to be constructive. But that 
conclusion was through the instructors' lens. What was the student perspective? A reality check on the student view of the impact of this reality television series as a teaching tool was needed. To achieve this, a survey was created and distributed to students in one business school class that was using Apprentice-based learning, and in two other 300level business school courses that were not specifically infusing Apprentice-based learning. Students were questioned on three tracks: their experience with The Apprentice, their attitudes after watching it, and the extent to which they learned about various aspects of business as a result of that viewing. Seventy students completed these questionnaires in the Spring 2004 semester, a few weeks after the first season of The Apprentice ended.

As Figure 8 shows, though only about a third of the students had been required to watch it for a class, a majority had watched the first season of The Apprentice. Even more planned to watch the second series. Threequarters of respondents wanted The Apprentice to be discussed in class, and a similar number reported that they would watch the program even if were not required viewing. The majority said they would like a class assignment based on The Apprentice though, interestingly, fewer wanted to simulate Apprentice-like competitions in class projects if there would be only one winner.

Figure 8: Student responses regarding experience with The Apprentice

\begin{tabular}{|c|c|c|}
\hline Experience With The Apprentice & $\underline{\% \text { Yes }}$ & \% No \\
\hline Watched the 2003-2004 TV series of The Apprentice & 57.1 & 42.9 \\
\hline Will watch The Apprentice when it returns to TV next Fall & 81.4 & 18.6 \\
\hline Would like The Apprentice to be discussed in class & 77.1 & 22.9 \\
\hline Would watch The Apprentice if it were not required & 72.7 & 27.3 \\
\hline Watched features about The Apprentice on other TV shows & 60.0 & 40.0 \\
\hline Would like a class assignment based on The Apprentice & 56.5 & 43.5 \\
\hline Told other people to watch The Apprentice & 54.2 & 45.7 \\
\hline $\begin{array}{l}\text { Would like a class project to simulate The Apprentice, with competition resulting in one } \\
\text { winner }\end{array}$ & 45.7 & 54.3 \\
\hline Were required to watch The Apprentice for a college class & 34.8 & 65.2 \\
\hline Applied to be a contestant on The Apprentice & 1.4 & 98.6 \\
\hline
\end{tabular}

In Figure 9, the attitudinal impact of The Apprentice on student viewers begins to be seen. Their attitudes are discerning. A large majority concluded that Mr. Trump knows a lot about business and hired the best candidate, and that they had learned a lot about how to succeed in business having watched the series. A smaller majority concluded that they would like to conduct business the way Mr. Trump does, or that they better understood how the business world really works having watched the series. Fewer still, though nearly half, of the students concluded that the Trump Organization treats male and female employees the same, or that it is the kind of place they would like to work in. Slightly less than one-third of the students felt that if they had been a candidate on The Apprentice they would have placed among the final four or better. Students who had watched The Apprentice, then, were critical viewers. Overall, they appeared to have identified the more authentic aspects of the series, and to have comprehended both its limitations and their own. 
Figure 9: Student responses regarding attitudes after watching The Apprentice

\begin{tabular}{|c|c|c|c|}
\hline Attitudes After Watching The Apprentice & \% Agree & \% Neutral & \% Disagree \\
\hline Mr. Trump knows a lot about business & 82.9 & 17.1 & 0.0 \\
\hline Mr. Trump was right to hire Bill & 80.0 & 17.5 & 2.5 \\
\hline $\begin{array}{l}\text { Learned a lot about how to succeed in business, having watched The } \\
\text { Apprentice }\end{array}$ & 73.1 & 19.2 & 7.7 \\
\hline Would like to conduct business the way Mr. Trump does & 61.0 & 17.1 & 22.0 \\
\hline $\begin{array}{l}\text { Better understand how the business world really works, having watched } \\
\text { The Apprentice }\end{array}$ & 58.5 & 31.7 & 9.8 \\
\hline The Trump Organization treats male and female employees the same & 48.0 & 24.0 & 28.0 \\
\hline The Trump Organization is kind of place would like to work & 46.2 & 7.7 & 46.2 \\
\hline $\begin{array}{l}\text { If had been on The Apprentice, would have been among the final } 4-\text { or } \\
\text { better }\end{array}$ & 31.7 & 34.1 & 34.1 \\
\hline
\end{tabular}

Figure 10 identifies the extent to which students reported strong learning about various aspects of business as a result of watching The Apprentice. They report that learning to have been high. A majority of respondents that watched The Apprentice reported they had learned a great deal about every aspect of business surveyed for. Virtually every student responded they had learned a great deal about teamwork, and almost as many reported having learned a great deal about leadership and communication. More than three out of four student viewers also reported they had learned a great deal about strategic planning and marketing. Fifty-eight percent responded having learned a great deal about office politics, career building, and ethics. These responses are consistent with the discerning nature of responses depicted in Figure 9, above. The aspects of business that students were most ambivalent about having learning from - office politics, career building, and ethics - corresponded with the more controversial and subjective aspects of the scenarios presented on The Apprentice.

Figure 10: Student responses regarding extent to which learned about aspects of business from The Apprentice

\begin{tabular}{|l|c|c|c|}
\hline Aspect Of Business Learned About By Watching The Apprentice: & \% A Lot & \% Average & \% Not Much \\
\cline { 1 - 3 } How Much & & & \\
Teamwork & 100.0 & 0.0 & 0.0 \\
Leadership & 96.2 & 0.0 & 3.8 \\
Communication & 92.3 & 7.7 & 0.0 \\
Strategic planning & 88.5 & 11.5 & 0.0 \\
Marketing & 76.9 & 15.4 & 7.7 \\
Office politics & 57.7 & 30.8 & 1.5 \\
Career building & 57.7 & 34.6 & 7.7 \\
Ethics & 57.7 & 26.9 & 15.4 \\
\end{tabular}

To further understand students' perspective of The Apprentice on their learning, an open ended question was asked at the end of the questionnaire: "If you would like to do so, please reflect upon the impact of The Apprentice on you, including the most important lesson you learned from watching it." A further indicator of the strength of student 
engagement with The Apprentice as a learning tool is that nearly one-third of the students who completed the survey answered the open-ended question. Their responses are depicted in Figure 11.

Figure 11: Student responses to open-ended question regarding impact of and lessons learned from The Apprentice

1. The effectiveness of the show comes from it being something new and educational in an intriguing manner. The reason for it grabbing attention was because between all the candidates, each person can relate to certain qualities and be criticizing what they did then they learn not to do it themselves. I would have probably never picked up two more effective books to show me how it is that humans win or lose and why. To be a leader takes a lot of learning to be as credible and likable to those you want following you.

2. The most important lesson I learned from watching The Apprentice is that women are seen to have more emotional ties, and it is a negative aspect for women. Another lesson is that ethical behavior is not a concern for Trump, but it is in the business world. Also, the best qualified like Kwame may not be the right fit like Bill. Bill did not get rattled, knows how to think outside the box, and incorporates his expertise to make his team successful. I would like to see Troy join Trump's organization because he is a significant asset along with Amy.

3. The Apprentice has given me somewhat of an inside look as to how the business world operates. It hasn't really made a big impact on me as a person but has shown me different perspectives as well as insights. The most important lesson that I've learned from the show is that at the end of the day, it is all about marketing. I have to say that the best that auditioned were not selected for the show. In order for ratings to sore to new heights, producers had to place a certain group of people in order for it to "work." But it is still a tremendous show.

4. It is hard to survive in the business environment.

5. I thought the show expressed a lot of information on how the business world works, but may not have given an honest representation of the politics that take place. I think what I most get from it though was how to be effective in team situations. Kwame probably only lost because he failed to keep Omarosa in line when she reportedly lied to him and the team. I think I learned how the executives expect you to act in those situations now, and we can all learn from this situation in addition to everything else discussed in the "boardroom."

6. I do not watch Omarosa on any program that features her as a guest. I realize there is nothing to fear about competition in the workplace. The apprentices were not very intelligent. I liked to learn from others' mistakes.

7. Lessons learned: The importance of impression management - you need the balance of likeability and credibility; perception gap - Omarosa had no idea how she was being perceived by the rest of the group, and this totally wiped out any credibility she had; professionalism is not something you can turn on and off - as a business person you have to be professional at all times.

8. It shows you really need to be strong in the business world and to stand up for yourself. Always think outside the box. Don't be too extreme, like Omarosa! It gets you nowhere except possibly committed.

9. I learned how important it is to think outside the box and how important it is to be a higher performer.

10. I learned that communication is key to success. When there is a lack of communication, it could be destructive.

11. Lessons learned: The importance of teamwork, how hostility can create hardships, and women should not use their sexuality to get ahead in the business world.

12. The Apprentice taught me many things about the business world I am about to enter. Teamwork was extremely important on this show. Being able to work with others when competing a task is extremely important.

13. The most important aspect I took is to have a good leader. Also have a team that work well together. I'm sure some stuff was different than real life because TV needs ratings to stay on. Most business work is boring.

14. I learned about teamwork and leadership. Listening is more important than talking. Be firm but understanding. 
15. I learned that teamwork consists of not only one person but the whole team; everyone is a leader.

16. I wish I had watched the show. As I remember during the series my brother and father would discuss it, and I'd have no idea what was going on. I was even interested in just who was who on the show. I am very much a person interested in reality shows. It would also help my knowledge of business to watch the next series.

17. I did not know about The Apprentice until this present survey. I promise myself to watch this show whenever the time is convenient just for the sake of learning. I will try my best to do so. Thank you.

18. From the few shows I watched, I found the game very interesting. Mr. Trump was a great person to host it because he has a great deal of business tactics to be able to judge the best person for the job.

19. I wasn't too interesting in watching it. I'm sure it's a decent show; I just never got around to it. While living on campus it is difficult to watch a program at a certain time. I rarely ever watch TV on campus.

20. No impact. Reality TV is not reality.

21. Even though Professor Eisner told us to watch it for class I would have watched it anyways. I learned so much from watching other people and seeing them make mistakes, and will hopefully learn from them. Life is too short to make all the mistakes yourself, so you might as well watch other people and learn from their mistakes. I also learned how important it is to have a college degree. I personally, as well as many other people, rooted for Troy. He handled himself and his projects very well. There was something about him that made him stand out from everyone else. The only thing that held him back from winning The Apprentice was that he did not receive a college education. Yes, he may have been successful in other ways without that piece of paper, but for this certain circumstance, it was crucial. Without a degree, Troy has already gone far and become successful. After he has completed his education (paid for by Trump) he will become much more successful and will achieve many great things, I am sure of it.

22. We must integrate the show in our classes. It contributed a lot to my understanding of the business world.

\section{OUTREACH}

Instructor and student perspectives appeared to be in sync. The Apprentice, to both, was a teaching tool with learning value. Moreover, student interest in accessing the series' learning potential had been expressed in assignment choices, assessed performance, and anonymous questionnaire responses. Were there students who might want to participate in such learning, but were unable to because they were not enrolled in classes where The Apprentice was a relevant or desired teaching tool?

Although student interest in The Apprentice was high among most of the students, it seemed to be especially intent in highest performing students. Some of these students were inductees of the College's Delta Nu chapter of Delta Mu Delta National Honor Society for Business Administration. The author of this paper serves as faculty advisor for that chapter, along with co-faculty advisor Professor Constance Crawford. Whereas the former's field is Business Management, the latter's field is Accounting. Together, these competencies span various majors that the student inductees pursue. Collaboration between the co-advisors on an Apprentice-linked event to be sponsored by the honor society chapter seemed a potentially valuable initiative. The honor society's student members were polled to determine their interest. Not only was their response immediate and enthusiastic, but they took the initiative to successfully apply for a grant from the Ramapo College Foundation to support two non-profit "Apprentice Watch" events in the following academic year - one for each upcoming season of The Apprentice. Figures 12 contains the rundown for the first of those events. 
Figure 12: Rundown for "Apprentice Watch" at Ramapo College, November 16, 2004

\begin{tabular}{|c|c|c|}
\hline \multirow[b]{2}{*}{ When } & \multicolumn{2}{|c|}{$\begin{array}{c}\text { "Apprentice Watch" at Ramapo College November 17, } 2004 \text { 6:00-9:00 PM The Pavilion } \\
\text { Presented by Delta Mu Delta/Delta Nu Chapter, with a Ramapo College Foundation grant }\end{array}$} \\
\hline & What & Who \\
\hline$\overline{6: 00-6: 10}$ & 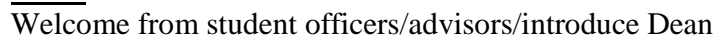 & Student Officer; Prof. Eisner: \\
\hline & Review program, handout packet, and upcoming events & Prof. Crawford \\
\hline $6: 10-6: 15$ & Greetings from School of Business Dean & Dean Champlin \\
\hline $6: 15-6: 25$ & Discuss: The Apprentice According to Students & Prof. Eisner lead discussion \\
\hline $6: 25-6: 30$ & Introduce "Who Will Be Apprentice 2" Contest & Student Officer \\
\hline $6: 30-6: 45$ & The Apprentice: A Guide to Literacy and Learning & Prof. Crawford \\
\hline $6: 45-7: 00$ & The Apprentice: Clip/Theme 1: Diversity & Student Officer intro; Expert Panel \\
\hline $7: 00-7: 15$ & The Apprentice: Clip/Theme 2: Lead/Decide & Student Officer intro; Expert Panel \\
\hline $7: 15-7: 30$ & The Apprentice: Clip/Theme 3: Professionalism & Student Officer intro; Expert Panel \\
\hline $7: 30-7: 45$ & The Apprentice: Clip/Theme 4: Ethics & Student Officer intro; Expert Panel \\
\hline $7: 45-8: 00$ & The Apprentice: Clip/Theme 5: Budgets/Finance & Student Officer intro; Expert Panel \\
\hline $8: 00-8: 05$ & Collect Ballots: Who Will be the Apprentice 2? & Student Officers \\
\hline $8: 05-8: 20$ & Team Challenge 1: Build top five list of lessons learned & Prof. Eisner/All \\
\hline $8: 20-8: 35$ & $\begin{array}{l}\text { Team Challenge 2: Who would you hire - Caroline, } \\
\text { Donald, or George? }\end{array}$ & Prof. Eisner/All \\
\hline $8: 35-8: 45$ & Lessons Learned/Award Prizes/Conclusions & Prof. Eisner lead discussion \\
\hline $8: 45-$ & Networking/dessert & All \\
\hline
\end{tabular}

The first “Apprentice Watch" event was designed to support the interests of students in career development. The event had two objectives: extend career-development learning, and facilitate networking. To accomplish this, the event set a ceiling of 75 guests, offered first-come invitations beyond the honor society to all students, and also extended invitations to honor society members who had graduated within the past five years. Student honor society officers were involved in the planning, and served as co-hosts. They selected themes illustrated by The Apprentice that they would like to focus on, and chose publicly available excerpts to illustrate those themes. Their choices reflected their priorities, and scenarios that had stimulated questions deserving further conversation. A panel of expert practitioners guided the ensuring discussion of diversity, leading/deciding, professionalism, ethics, and budgets/finance. Team challenges were used to stimulate networking. The event drew a capacity crowd, whose responses were enthusiastic. Figure 13 depicts the follow up event, "Apprentice Watch 2," held six months later.

Figure 13: Rundown for "Apprentice Watch 2" at Ramapo College, May 11, 2005

\begin{tabular}{|c|c|c|}
\hline \multirow[b]{2}{*}{ When } & \multicolumn{2}{|c|}{$\begin{array}{l}\text { "Apprentice Watch 2" at Ramapo College May 11, } 2005 \text { 6:00-9:00 PM The Pavilion } \\
\text { Presented by Delta Mu Delta/Delta Nu Chapter, with a Ramapo College Foundation grant }\end{array}$} \\
\hline & What & Who \\
\hline \multirow[t]{2}{*}{$\overline{6: 00-6: 05}$} & $\overline{\text { Welcome }}$ & 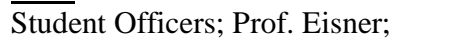 \\
\hline & Preview program, handout packet, and upcoming events & Prof. Crawford \\
\hline \multirow[t]{6}{*}{$6: 05-6: 15$} & Discuss: The Apprentice - According to Students & Prof. Eisner lead discussion \\
\hline & Apprentice 2: Men v. women & \\
\hline & Apprentice 3: Book smarts v. street smarts & \\
\hline & Rate: Reality v. Entertainment/drama (1-4) & \\
\hline & List/tell: Questions stimulated by The Apprentice & \\
\hline & Introduce "Who Will Be Apprentice 3" Contest & \\
\hline $6: 15-6: 25$ & The Apprentice: A Guide to Literacy and Learning & Prof. Crawford \\
\hline $6: 25-6: 40$ & The Apprentice: Video Theme 1: Gender Relations & Student Officer intro; Alumni Panel \\
\hline $6: 40-6: 55$ & The Apprentice: Video Theme 2: Marketing Rules & Student Officer intro; Alumni Panel \\
\hline
\end{tabular}




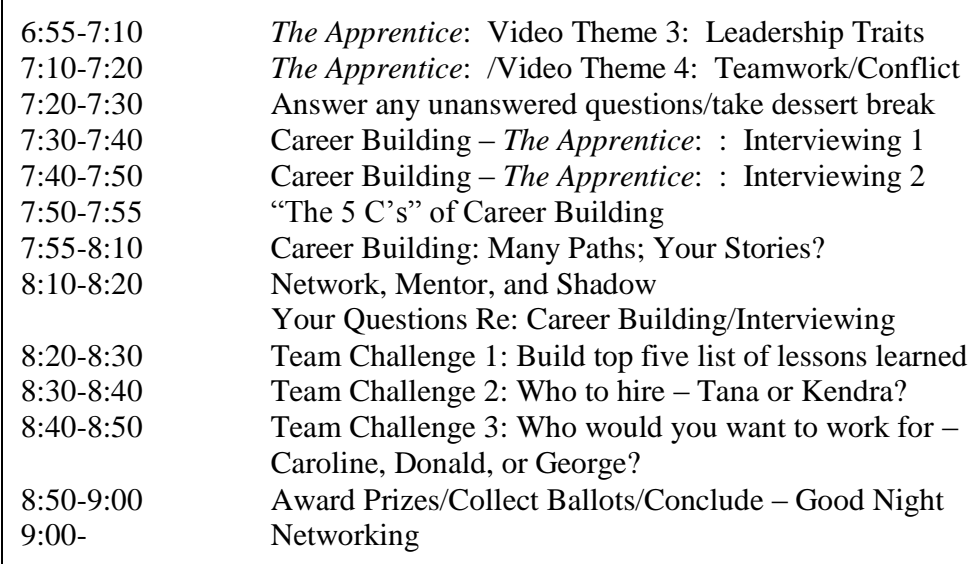

The Apprentice: Video Theme 3: Leadership Traits The Apprentice: /Video Theme 4: Teamwork/Conflict Answer any unanswered questions/take dessert break Career Building - The Apprentice: : Interviewing 1 Career Building - The Apprentice: : Interviewing 2 "The 5 C's" of Career Building Career Building: Many Paths; Your Stories?

Network, Mentor, and Shadow

Your Questions Re: Career Building/Interviewing Team Challenge 1: Build top five list of lessons learned Team Challenge 2: Who to hire - Tana or Kendra? Team Challenge 3: Who would you want to work for Caroline, Donald, or George?

Award Prizes/Collect Ballots/Conclude - Good Night Networking

Student Officer intro; Alumni Panel

Prof. Eisner intro; Alumni Panel

Panel Answer Questions

Prof. Eisner intro; All discuss

Prof. Eisner intro; All discuss

Prof. Eisner

Alumni Panel

Prof. Eisner

Prof. Crawford; Alumni Panel

Prof. Eisner; All; Alumni Panel Judges

Prof. Crawford; All; Panel Judges

Prof. Eisner; All; Panel Judges

Prof. Crawford; Eisner; Student Officers All

The second "Apprentice Watch" event had objectives similar to its predecessor, extended similar invitations, again involved student officers of the honor society throughout the planning process, and again used team challenges to facilitate networking. Perhaps because "Apprentice Watch 2" occurred in the Spring semester, with graduation imminent, several students requested that career building receive special attention at this event. As a result, faculty advisors selected excerpts from The Apprentice episode in which the series' finalists are interviewed by corporate executives, followed it with specific pointers, and showcased the panelists as real-world illustrators of strategic career building, as seen in Figure 13, above. This time, the panel of experts was comprised of Ramapo College alumni now established in successful but varied careers, and who had taken various routes to achieve their current positions.

Figure 14 illustrates the attentiveness and depth of student thinking stimulated by watching The Apprentice. It contains a summary of the themes students selected to illustrate and focus on in "Apprentice Watch 2" - gender relations, marketing rules, leadership traits, and teamwork/conflict - and the questions they raised for student Marco Viotti, then President of the Ramapo College chapter of Delta Mu Delta National Honor Society.

\section{Figure 14: “Apprentice Watch 2" summary of series highlights prepared by student officer, Marco Viotti}

VIDEO THEME \#1: Gender Relations, Sensual Charm - "If you've got it, use it!?"

- Three scenes show minor conflicts between women, caused by the use of "womanly charm" in business

- Heidi rolls her eyes as Omarosa finds a 'connection' with the artist

- Katrina's use of charm is not approved by her female teammate

- Angie sees Erin as a threat, partly because she is good looking

- Although most women on the show seem to approve of the use of 'charm' in business, they still need to make a point about other women on the show using it. Do they really think it is acceptable then? No scene on the tapes showed males commenting on it.

VIDEO THEME \#2: Marketing Rules - "Believe in what you sell," and "Don't sell when it's already sold"

- Heidi tries to understand the artist's work

- In the boardroom, the group which liked their product wins by a landslide. Can this be a lesson for recent graduates? Does one have to necessarily like the product a company offers to work in it?

- The child executive clearly agrees to help Kwame's team, but Troy still feels the need to convince him. Where can this rule be applied in daily business negotiations?

VIDEO THEME \#3: Leadership Traits - “Are leaders born with them or can one learn them?" And body language in a team as an important component of cohesion

- Kwame single-handedly convinces his team to choose the riskier artist. Having the team join hands creates a 'pact'. Would that be done in corporate environments? 
- $\quad$ Nick makes an 'executive decision' by choosing the artist he prefers. His team members accept, yet have a bad feeling. Nick explains how he was able to keep team morale high by showing energy and enthusiasm

- Trump confirms Nick's theory, by saying that, after 'brains', energy is the most important trait in an executive. Are leaders born?

- Bad example of leadership: Sam. We see a phone monologue, showing he does not communicate with his teammates. In the boardroom, they claim they had to 'calm him down'. Could this be too much energy and passion? Is energy any good if the communication skills are missing?

- Tana shows good leadership. First, she mends a confrontation between Jennifer and Craig. Later, faced with a big problem, she decides to move on to keep the team morale high. She is praised by Craig as a great leader, because she knows how to 'steer.' Is this a skill that can be learned? How did Tana win the respect of her team? Could it be her age, knowledge, or charisma?

Once again, attendance for the college-wide Apprentice Watch event reached its capacity of some 75 guests. Their response was as highly positive for this second event as it had been for the first.

\section{WIDE HORIZONS}

Are these student responses to The Apprentice unique to Ramapo College? A review of the literature suggests that they are typical. For instance, an article in The Atlanta Journal-Constitution interviewing various MBA students and professors throughout metropolitan Atlanta about their learning from The Apprentice concluded that they had gained lessons about the real-world. Figure 15 highlights the learning reported (Ho, 2004). Overall, that learning is similar to the learning expressed by Ramapo College students throughout this paper.

Figure 15: Lessons learned from The Apprentice according to MBA students and professors in Atlanta

- Sex sells?: The women early on used their looks to sell lemonade and liquor and get deals. DT called them on it, and said they didn't need to cross the line of sexuality to win. The women were duly chastened and have scaled back that tactic.

- Learn what your client wants: When the team designed ad campaigns for a client, the female team talked to the company officials to understand what type of ads they wanted. The men didn't, and lost.

- Stand up for yourself in front of the boss: More than once, contestants who didn't defend themselves sufficiently have lost, having shown weakness in the face of danger. The more abrasive survived by holding ground and belittling teammates. Passivity, to Donald Trump, is worse than rudeness.

- Loyalty to the team trumps all: Disloyalty doesn’t sit well with Donald Trump.

- Think outside the box: Creativity, backed by strong organization, tends to be a winning combination.

Ripple effects of The Apprentice as a learning tool appear widespread. Students at Weber State University in Ogden, Utah, created a website to provide a forum for exploring ethical issues depicted on The Apprentice (Deggans, 2004). After broadcast of an episode that relates to her class, a Brandeis University professor asks her students why the winning team won, and how the situation might be approached in a different way. The Senior Associate Dean at University of San Francisco's School of Business and Management suggests that students track The Apprentice candidate they most relate to and see how that candidate does, as the real lessons will be in the feedback the contestant receives in the Boardroom (Lee, 2004). The University of Washington at Seattle created a Management course entitled Management Lessons from The Apprentice in which eighty undergraduates watch each episode, and come up with business plans for the featured task (Talcott, 2004). A marketing class at Northern Illinois University assigns student teams a different task every week, student film crews videotape the team at work, the tape triggers an Apprentice-style Boardroom session with alumni who own their own companies and decide who stays in, and winners 
receive scholarships and a grade of "A" (Apprentice NIU Style, 2004). And Donald Trump has established Trump University, with the motto "we teach success." At www.trumpuniversity.com the "learning" link accesses modules in self-assessment, wealth creation, marketing, real estate, and entrepreneurship.

\section{ON THE OTHER HAND}

Some say that the strongest learning lessons from The Apprentice come from what did not work for the candidates. According to Maureen Moriaraty, a Certified Business and Executive Coach, "The Apprentice could service as a mini case study in any Business College or University on business and leadership, but mostly as the non example ... it hardly should be used as the model for good leadership in business." Competencies she identifies as important to develop based on counter-examples depicted in the series include emotional self-control, clarification of goals and responsibilities, conflict resolution rather than catfights, sex sells but is not a winning leadership strategy, behaviorally specific feedback, model the behavior you want, coach more and manage less (Moriaraty, 2005).

Sykes Business School Dean Joe McCann has other concerns. He describes The Apprentice as portraying a "feudal model of leadership ... (violating) about every prevailing leadership model in organizations today ... It fills (undergraduates) with fear, (saying) 'This is what I have to aspire to?” (Deggans, 2004).

Still others criticize the firing process that is the focus of the weekly Boardroom scenes on The Apprentice. A USA Today article disparages Mr. Trump for oversimplifying the termination process. The author states that, in the real world, the firing practices that Mr. Trump uses on the series "would give his lawyers ulcers. They would tell him to take a deep breath and ninety days to build a case ... he would be told to document, document, document to convince a jury (s/he) had it coming ... Firing people, done wrong, might expose Trump to a lawsuit" (Jones, 2004).

On the other hand, the Newsweek article cited earlier put it this way: "If the business of America is business, The Apprentice is its first video diary" (Naughton, 2004). And a Boston Globe article that interviewed business school professors nationwide about the relative merits of The Apprentice as a teaching tool determined this: "The professors said The Apprentice will never take the place of textbooks or traditional case studies. But they agreed that it can have a place alongside them" (Talcott, 2004).

In the summer of 2004, an edition of the AACSB International publication BizEd contained an interesting point-counterpoint feature on The Apprentice. Dean Denis Fred Simon of the Lolly School of Management and Technology at Rennselar Polytechnic Institute wrote the "You're Hired" piece, while Professor of Management David Cadden of the School of Business at Quinnipiac University wrote the "You're Fired" piece. Dean Simon sees The Apprentice as having "a lasting effect on business education." In his view, the series accurately shows that winning requires great persuasive power and skill, that ability to lead and build teams are critical competencies, and that high performance must occur on both individual and team levels. His criticism is leveled not at The Apprentice, but at business education, which he says "must do more than ever to recreate real-life business challenges for students ... we should make sure students face similar challenges and learn to think on their feet" - though without the backstabbing competition of The Apprentice (Simon, 2004).

In his counterpoint piece, Professor Cadden notes that business professors should take notice of The Apprentice. He cautions, though, that as with all modes of instruction educators must ask, "What, precisely, do we want to teach our students, and ... what should our students actually learn." Professor Cadden advises educators to pinpoint what students are taking from their viewing of The Apprentice. He emphasizes the importance of including the normative element - what the behavior should be, along with the descriptive element - how the real world operates. His conclusion: "The Apprentice falls short of offering our students meaningful insights. Business education, on the other hand, must fill the void to make sure students aren't taking the show's message without qualification ...When a show like The Apprentice so engages our students, it provides us with an excellent forum for active dialog." 


\section{CONCLUSION}

The reality television series The Apprentice has attracted younger viewers in record number. Most of today's college students fall within that age range. Academic and practitioner literature provide far-reaching foundation upon which to create pedagogy to extend the impact of The Apprentice as a teaching tool reaching those students. The pedagogy created for business school students at Ramapo College of New Jersey is illustrative of the many and disparate initiatives educators have undertaken to access this teaching opportunity. The Apprentice-linked initiatives depicted in this paper began simply, and developed one student response at a time. Those initiatives have provided a way to connect with the students in a place that they frequent outside the classroom that purports to realistically portray the career path and future for which most of them are preparing. There, the Apprentice-linked pedagogy offers a means to provide both the descriptive and normative elements proscribed by Cadden, the simulation of real-life challenges proscribed by Simon, and the demarcation of examples from non-examples proscribed by Moriaraty.

Instructors interested in creating Apprentice-linked pedagogy whose class sessions are already tight may wonder where they will find the time to fit it in. The initiatives designed at Ramapo College described in this paper may present a place to start. They were offered in classes that enroll a variety of student majors, and resonated with the all-college student body. They provide modalities that can be infused into a class session along with or in lieu of other cases, or provide ancillary learning vehicles outside the formal classroom. In my classes, they are but one of several teaching tools all with the same goal - to facilitate, extend, and deepen student learning.

It is important to note that this use of Apprentice-linked pedagogy has not promoted the Trump Organization or portrayed the series' content as behavior or precepts to model. Rather, these initiatives have given a forum for analytic questioning, critical thinking, and candid conversation provoked by the series, and for academic response.

Creating pedagogy based on solid ground, assessing its effectiveness, refining and replicating it, incorporating it with other learning modalities, and assuring it is a means to facilitate achievement of overarching course objectives - rather than an end in itself - is labor intensive and complex work. Is it worth it? A student response to the open-ended question in the student questionnaire regarding Apprentice viewing signifies and resonates the affirmative:

I learned so much from watching other people and seeing them make mistakes, and will hopefully learn from them. Life is too short to make all the mistakes yourself, so you might as well watch other people and learn from their mistakes. I also learned how important it is to have a college degree.

\section{REFERENCES}

1. _ (2005, December 16). Apprentice finale boosts NBC. Reuters.

$2 . \quad$ (2005, January 19). Apprentice heading to Broadway. CBS News.

3. _ (2004, October 4). Apprentice NIU style. Chicago Tribune, p. 12.

4. (2005, May 24). Lessons learned from The Apprentice. American Management Association Website. Retrieved May 24, 2005, from http://www.amanet.org/events/apprentice/lessons_learned.

5. Bloomberg, David (2005, January 20). What Apprentice 3 applicants should have learned. Reality News Online. Retrieved May 24, 2005, from http://www.realitynewsonline.com/cgi bin/ac.pl?mode=4\&article=art.

6. Cadden, David (2004, July/August). You're Fired! Biz/Ed (Published by AACSB International), 5.

7. Career Center. Lessons learned from The Apprentice: Interview strategies. Career.berkeley.edu. Retrieved December 17, 2005, from http://career.berkelety.edu/Article/0501031-db.stm).

8. Deggans, Eric (2004, April 13). Trump University. St. Petersburg Times.

9. Ho, Rodney (2004, March 3). Professor Trump - MBA students get real-world lessons from the surreal world of The Apprentice. The Atlanta Journal-Constitution, p. E1.

10. Jones, Del (2004, March 5). Trump makes firing people look easier than reality: Touchy task requires planning. USA Today, p. B6. 
11. Lee, Ellen (2004, January 31). Donald Trump's The Apprentice has business lessons to teach. Contra Costa Times.

12. Levin, Gary (2004, September 9). Apprentice: Back to work with a crucial job. USA Today, p. 3D.

13. Moriaraty, Maureen. How future The Apprentice candidates can win. Pathways to Change. Retrieved May 24, 2005, from http://www.pathtochange.com/whitepapers_html.

14. MSN Careers. Lessons from The Apprentice: Surviving the corporate jungle. CareeerBuilder.com. Retrieved April 20, 2004, from http://msn.careerbuilder.com/Custom?MSN/CareerAdvice/236.thm?

15. Muscato, Gina (2004, February 2). Must-wee TV shows are created, popular because we keep watching. Finger Lake Times.

16. Naughton, Keith (2004, March 1). The world according to Trump. Newsweek,143 (9), p 48 (8). Retrieved May 28, 2004, from Academic Search Premiere database.

17. Purdy, Kevin (2004, March 10). Some Buffalo NY-Area workers learn from business-reality TV show. Knight Ridder Tribune Business News,. p. 1.

18. Simon, Denis Fred (2004, July/August). You're hired! Biz/Ed (Published by AACSB International), 5.

19. Talcott, Sasha (2004, April 15).The Apprentice: A case study - Business schools nationwide find some real lessons in reality TV hit. The Boston Globe.

\section{ENDNOTES}

1. March of Dimes National Birth Defects Foundation, Communications Department, 1985-1987; WNET/Thirteen Television - New York, 1975-1983; Presidential Campaign and National Political Party, Communications Department, 1972-1974; National Urban League, 1969-1971.

2. Graduate course s in media and audience impact at Harvard University and MIT, 1971-1974; continuing education courses in television programming and writing at The New School, 1974-1975.

3. Business Communication (BMGT 307) teaches the strategic application of interpersonal, oral, and written competencies to achieve business goals; organizational Theory and Behavior (BMGT 327) teaches strategic routes to individual, group, and systematic high performance; and Principles of Contemporary Arts Management (BMGT/CCOM 302) teaches strategic approaches to managing organizations in the media, entertainment, arts, and related promotional industries. 


\section{Notes}


1 March of Dimes National Birth Defects Foundation, Communications Department, 1985-1987; WNET/Thirteen Television - New York, 19751983; Presidential Campaign and National Political Party, Communications Department, 1972-1974; National Urban League, $1969-1971$

2 Graduate courses in media and audience impact at Harvard University and MIT, 1971-1974; continuing education courses in television programming and writing at The New School, 1974-1975.

3 Business Communication (BMGT 307) teaches the strategic application of interpersonal, oral, and written competencies to achieve business goals; Organizational Theory and Behavior (BMGT 327) teaches strategic routes to individual, group, and systematic high performance; and Principles of Contemporary Arts Management (BMGT/CCOM 302) teaches strategic approaches to managing organizations in the media, entertainment, arts, and related promotional industries.

\section{$\underline{\text { Notes }}$}

